\title{
Evaluation of the heat resistance of pathogenic Listeria monocytogenes in milk and milk products in Sri Lanka
}

\author{
VS Jayamanne $^{1}$ and U Samarajeewa ${ }^{2}$ \\ ${ }^{1}$ Department of Food Science \& Technology, Faculty of Agriculture, University of Ruhuna, Kamburupitiya, \\ Sri Lanka \\ ${ }^{2}$ Department of Food Science \& Technology, Faculty of Agriculture, University of Peradeniya, Peradeniya, \\ Sri Lanka
}

Accepted: $26^{\text {th }}$ July 2010

\begin{abstract}
Listeria monocytogenes, which is a food-borne pathogen often isolated from milk and milk products, causes listeriosis in pregnant women, newborns, older adults and immuno-suppressed people. Listeria is said to be more resistant to heat treatments and the present study investigated the effects of current heat treatments on inactivation of Listeria in milk. Two isolates of L. monocytogenes, namely FSTLC2 and FSTLC55, were introduced to sterilized milk at population levels of $10^{2}$ and $10^{9} \mathrm{cfu} / \mathrm{ml}$ and were subjected to various temperature-time combinations. Listeria was enumerated using the FDA Listeria Enrichment Broth (LEB; Oxoid Ltd) and Modified Oxford Agar (MOX; Oxoid Ltd) medium. The Thermal Death Time (TDT) and Thermal Death Rate (TDR) curves were also constructed using thermal resistance data. The slope of the TDT curve (z) and the slope of the TDR curve (D; Decimal Reduction Time) were also determined using the statistical software package Minitab (release 8.21). It was observed that the normal pasteurization treatments of $62.8^{\circ} \mathrm{C}$ for $30 \mathrm{~min}$ (LTLT; Low Temperature Long Time) and $71.7^{\circ} \mathrm{C}$ for $15 \mathrm{sec}$ (HTST; High Temperature Short Time) appear to be adequate to destroy a Listeria population of $10^{2} \mathrm{CFU} / \mathrm{ml}$ in milk, but not a population of $10^{7} \mathrm{cfu} / \mathrm{ml}$. A z value of $7.6^{\circ} \mathrm{C}$ and a $\mathrm{D}_{71.7}{ }^{\circ} \mathrm{C}$ value of $2.9 \mathrm{sec}$ were observed for L. monocytogenes in milk. The current heat treatment techniques used in the dairy industry need to be reviewed and necessary modifications introduced to ensure a complete elimination of this pathogen. Moreover, the $\mathrm{z}$ and $\mathrm{D}_{71.7}{ }^{\circ} \mathrm{C}$ values observed in the present study may be used in devising sound heat treatment techniques as well as suitable Hazard Analysis Critical Control Points (HACCP) systems in the dairy industry.
\end{abstract}

Keywords: Listeria monocytogenes, Thermal inactivation, Heat resistance, Pasteurization, Thermal Death Time, Thermal Death Rate

\section{INTRODUCTION}

Listeria monocytogenes, which is a Gram-positive, facultatively anaerobic, cold tolerant, salt tolerant, non-spore forming and non-acid fast rod often found in soil and water, and faeces of animals, is a relatively recent food-borne pathogen reported mostly from developed countries (Maijala et al. 2001; Karakolev 2009). L. monocytogenes is a food -borne pathogen of high concern to the food industry as its ubiquitous occurrence in the environment can lead to contamination of foods. L. monocytogenes has been isolated from soil and water, fresh vegetables, potato, faeces of animals, cattle and faeces of humans, newborn infants, silage, raw beef and chicken, and Soymilk. The toxic substance produced during the exponential growth phase of $L$. monocytogenes is designated listeriolysin $\mathrm{O}$ (hemolysin), which causes hemolysis of blood agar in in-vitro studies. When L. monocytogenes is contracted through the oral route, it apparently colonizes the intestinal tract by mechanisms that are poorly understood. From the intestinal tract, the organism invades tissues including the placenta in pregnant women, and enters the blood stream, from which it reaches other susceptible body tissues. Listeriosis, the illness caused by this bacterium, affects mostly pregnant women, elderly, newborns, and the immuno-suppressed adults due to AIDS, alcoholism, diabetes, cancer, cardiovascular disease, kidney disease, renal transplant, and corticosteroid therapy (Rocourt et al. 2000). When susceptible adults contract the disease, meningitis and septicemia are the most commonly recognized symptoms. The non-pregnant healthy individuals who are not immuno-suppressed are fairly resistant to infection by L. monocytogenes. Infected pregnant women may experience only mild flu-like illness, and the illness can be transmitted from mother to the fetus through the placenta resulting in abortion, premature birth, stillbirth, or serious health problems for the newborn child. The mortality rate of the disease is approximately $25 \%$ (USDA 1999).

Milk and milk products have received much attention because they have been reported to harbor $L$. monocytogenes to a much higher extent compared

\footnotetext{
*Corresponding author; vsjayamanne@fst.ruh.ac.lk

Paper presented at the $2^{\text {nd }}$ National Symposium, Faculty of Agriculture, University of Ruhuna
} 
to other foods. L. monocytogenes has been isolated from cow milk, goat milk, cheese, and pasteurized milk in Sri Lanka (Jyamanne and Samarajeewa 2001). There have been reports of Listeria outbreaks associated with dairy products (Farber and Peterkin 1991). Cow milk has been implicated in food-borne fatal listeriosis. The ability of L. monocytogenes strains to proliferate in raw milk even under refrigerated condition is well documented. Hitherto only two suspected human cases of listeriosis have been reported in Sri Lanka. The first is two children suffering from meningitis (Jayasundara et al. 1962; Withana and Mirando 1967), and two cases (children) with headache, fever and a rash (Wijesundera et al. 1992). L. monocytogenes has been isolated from goslings, chickens, buffaloes, and goats in Sri Lanka (Bandaranayaka and Nair 1962; Bandaranayaka and Fernando 1962).

Though milk and milk products were reported to transmit food-borne listeriosis, only two studies have been reported in Sri Lanka to ascertain the safety of the dairy products. In a survey on Listeria in foods, it was demonstrated that the percentage of L. monocytogenes positive samples was highest among vegetables (49\%), second in chicken (34\%), and lowest in dairy products (26\%) (Gunasena et al. 1995). They further observed that 5 pasteurized milk $(31 \%), 3$ raw milk $(25 \%)$ and 4 ice cream (33\%) samples contained L. monocytogenes. In a similar study, of the samples tested (265), 39 samples $(15 \%)$ contained virulent L. monocytogenes. Cow milk (29\%), goat milk $(27 \%)$, pasteurized milk (17\%), and cheese (33\%) samples contained virulent strains of L. monocytogenes (Jayamanne \& Samarajeewa 2001).

Listeria is said to be more heat resistant to heat processing than other foods, especially when buffered by proteinaceous foods. Although there have been reports on the presence and thermal properties of Listeria in milk and milk products in other countries, no such studies have been reported from Sri Lanka. Therefore, the present study investigated the thermal resistance of isolates of $L$. monocytogenes in milk and milk products in Sri Lanka.

\section{MATERIALS AND METHODS}

Separate experiments were carried out to determine the optimum pasteurization-time combination required to inactivate Listeria in milk, to determine the thermal resistance of Listeria from pasteurized

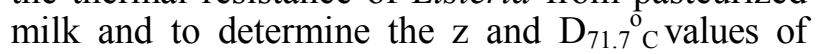
Listeria in bovine milk during heat processing.

\section{Determination of the optimum pasteurization temperature-time combination required to inactivate Listeria}

A commercial brand of sterilized milk (fat $\sim 3.5 \%$, protein $\sim 4 \%$ ) available in the market was selected as the milk based food system for the experiment. Sterilized milk was first tested for Listeria using the FDA Listeria Enrichment Broth (LEB; Oxoid Ltd., Basingstoke, UK) and Modified Oxford Agar medium (MOX; Oxoid Ltd.) in order to ensure that milk was not contaminated with Listeria.

In the enumeration process of the organism, Listeria in milk was first enriched in FDA Listeria Enrichment Broth. Samples $(25 \mathrm{ml})$ were blended with LEB $(225 \mathrm{ml})$ at $12,000 \mathrm{rpm}$ for $2 \mathrm{~min}$ in a Waring blender. The resulting solution was incubated at $35^{\circ} \mathrm{C}$ for $48 \mathrm{~h}$ for selective enrichment and the selective isolation of Listeria was done in MOX. Enriched samples were next streaked onto MOX Agar plates and incubated at $35^{\circ} \mathrm{C}$ and examined for colonies with black halos after 24,48 and $72 \mathrm{~h}$. Single colonies growing on the MOX medium were isolated and transferred to $\mathrm{MOX}$ agar slants in McCartney bottles and incubated $\left(35^{\circ} \mathrm{C}\right)$ until there was a sufficient growth. The MOX agar slants were stored in the refrigerator $\left(3^{\circ} \mathrm{C}\right)$ pending confirmatory morphological and biochemical tests. MOX agar slants were sub-cultured at 3-month interval to ensure the viability of organisms. The tests [microscopy on wet mount, Gram staining, catalase test, methyl red (MR) test, Vogus-Proskauer (VP) test, $\mathrm{H}_{2} \mathrm{~S}$ production, color changes in Triple Sugar Iron Agar, color changes in Urea Agar, hydrolysis of aesculin and CAMP test] were carried out to confirm the presence of Listeria in the food samples.

L. monocytogenes FSTLC2 (University of Peradeniya Culture Collection), isolated previously in one of our previous studies (Jayamanne and Samarajeewa, 2001) from raw cow milk was enriched in LEB at $35^{\circ} \mathrm{C}$ for $48 \mathrm{~h}$. A loopful of enriched Listeria culture was aseptically transferred to McCartney bottles containing $20 \mathrm{ml}$ of Tryptose Broth (Oxoid Ltd.), incubated for another $24 \mathrm{~h}$ at $35^{\circ} \mathrm{C}$. After $24 \mathrm{~h}$ of incubation in Tryptose Broth, the Listeria cells at the late stationary phase were harvested by centrifugation at $6000 \times \mathrm{g}$ for $20 \mathrm{~min}$. Listeria was introduced to sterilized milk to have an approximate initial Listeria population of $10^{2} \mathrm{cfu} / \mathrm{ml}$ and the other with $10^{7} \mathrm{cfu} / \mathrm{ml}$. Two experiments were carried out separately, one with an approximate initial Listeria population of $10^{2} \mathrm{cfu} / \mathrm{ml}$ and the other with $10^{7} \mathrm{cfu} / \mathrm{ml}$.

Sterilized milk with Listeria was subjected to different temperature regimes (from 50 to $80^{\circ} \mathrm{C}$ at $5^{\circ} \mathrm{C}$ increments) for different time periods $(5,10,15$, 20,25 and $30 \mathrm{sec}$, and $1,2.5,5,10,15,20,25,30$, $35,40,45,50,55,60,70,80,90,100,110,120$, 
130,140 , and $150 \mathrm{~min}$ ) on a constant temperature water bath (Kayagaki-DC3). Predetermined comeup times were allowed prior to the actual experiments. Samples $(1 \mathrm{ml})$ in duplicate were aseptically taken in the beginning, and after heat treatments, and enriched in LEB for $48 \mathrm{~h}$ at $35^{\circ} \mathrm{C}$. Enriched cultures were streaked on to MOX Agar plates and incubated at $35^{\circ} \mathrm{C}$ for $48 \mathrm{~h}$, and examined for typical L. monocytogenes colonies with black/brown halos. The minimum time periods, required for the total inactivation of $L$. monocytogenes with regard to different temperature regimes, were recorded.

\section{Determination of the thermal resistance of $L$. monocytogenes isolates from pasteurized Milk}

L. monocytogenes FSTLC55 (University of Peradeniya Culture Collection) previously from pasteurized milk was aseptically introduced to sterilized milk (at populations of $10^{2} \mathrm{cfu} / \mathrm{ml}$ ) and was subjected to different temperature regimes and time periods as described earlier.After giving heat treatments, samples were enriched in LEB and inoculated on MOX Agar plates and examined for any sign of the survival of Listeria.

\section{Determination of $\mathrm{z}$ and $\mathrm{D}$ values for $L$. mono- cytogenes in bovine milk}

The Thermal Death Time (TDT) curve was constructed using previous data, i.e., inactivation time for Listeria with regard to different temperature values used. The slope of the TDT curve ( $\mathrm{z}$ ) was determined using the statistical package Minitab (release 8.21). The decimal reduction time (D) values for L. monocytogenes in cow milk with regard to HTST pasteurization treatment $\left(71.7^{\circ} \mathrm{C}\right.$ for 15 $\mathrm{sec}$ ) was determined in a separate experiment. The commercial brand of sterilized milk used in the previous studies was used in this experiment as well. L. monocytogenes FSTLC2 from the stored culture collection was enriched first in LEB for $48 \mathrm{~h}$ at 35 ${ }^{\circ} \mathrm{C}$, transferred to Tryptose Broth, and incubated for further $24 \mathrm{~h}$ at $35^{\circ} \mathrm{C}$. Listeria cells at the late stationary phase were harvested at $6,000 \times \mathrm{g}$ for $20 \mathrm{~min}$ and introduced to sterilized milk $(250 \mathrm{ml})$ in an Erlenmeyer flask to make a final Listeria population of $\sim 10^{5} \mathrm{cfu} / \mathrm{ml}$. The Erlenmeyer flask was incubated at $71.7^{\circ} \mathrm{C}$ on a constant temperature water bath. Samples $(1 \mathrm{ml})$ in duplicate were aseptically taken from Erlenmeyer flask at $3 \mathrm{sec}$ intervals. These samples were enriched in LEB for $48 \mathrm{~h}$ at $35^{\circ} \mathrm{C}$. A dilution series (from 1:10 to 1:100000) with buffered water was prepared, and two MOX Agar plates from each dilution were inoculated using the surface plate count technique. MOX Agar plates were incubated at $35^{\circ} \mathrm{C}$ for $48 \mathrm{~h}$ and a surface count was taken using a digital colony counter (KayagakiDC3). Logarithmic of the survival number of or- ganisms ( $\mathrm{Y}$ axis) was plotted against time ( $\mathrm{X}$ axis). The time required to reduce the number of organisms by one log cycle is the decimal reduction time (D) in relation to the temperature regime used, $71.7^{\circ} \mathrm{C}$ used in this experiment.

\section{RESULTS AND DISCUSSION}

It was observed in the present study that the normal pasteurization protocols such as HTSTb and LTLT treatments are adequate to inactivate a low Listeria population of $10^{2} \mathrm{cfu} / \mathrm{ml}$ but not a high population of $10^{7} \mathrm{cfu} / \mathrm{ml}$.

\section{Evaluation of the most effective pasteurization temperature-time combination}

The observed temperature-time combinations required to ensure complete inactivation of the $L$. monocytogenes FSTLC2 from raw cow milk under laboratory conditions is given in Table 1 . It was observed that the normal pasteurization treatments of $62.8{ }^{\circ} \mathrm{C}$ for $30 \mathrm{~min}$ (LTLT), and $71.7{ }^{\circ} \mathrm{C}$ for 15 sec (HTST) appear to be adequate to destroy a Listeria population of $10^{2} \mathrm{cfu} / \mathrm{ml}$ in milk, but not at population of $10^{7} \mathrm{cfu} / \mathrm{ml}$ as shown in Table 1, Fig. $1 \mathrm{a}$ and Fig. 1b. It was reported by many early scientists that LTLT (Mackey and Bratchell, 1989) and HTST (Bunning et al. 1992) treatments are adequate to destroy Listeria in milk. Numerous conflicting reports concerning the unusual heat resistance of L. monocytogenes in milk can be found in the early literature. L. monocytogenes survived $15 \mathrm{sec}$ in milk at $100^{\circ} \mathrm{C}$ (Ozgen, 1952). L. monocytogenes was not completely inactivated until the milk was held at $65{ }^{\circ} \mathrm{C}$ for $5 \mathrm{~min}, 75{ }^{\circ} \mathrm{C}$ for $2 \mathrm{~min}$, or $80^{\circ} \mathrm{C}$ for $3-5 \mathrm{~min}$ (Stenberg and Hammainen, 1955). L. monocytogenes survived $30-40 \mathrm{sec}$ at $65^{\circ} \mathrm{C}, 10 \mathrm{sec}$ at $75^{\circ} \mathrm{C}$, and $\sim 1 \mathrm{sec}$ at $85^{\circ} \mathrm{C}$ (Dedie and Schulze 1957). But, later scientists found many inadequacies in the methodologies employed in these early experiments, and the validity of these

Table 1 Thermal inactivation times of $L$. monocytogenes (FSTLC2) suspended in milk at populations of $10^{2}$ and $10^{7} \mathrm{cfu} / \mathrm{ml}$

\begin{tabular}{lrr}
\hline Temperature $\left({ }^{\circ} \mathrm{C}\right)$ & \multicolumn{2}{l}{$\begin{array}{l}\text { Thermal inactiva- } \\
\text { tion time }\end{array}$} \\
\cline { 2 - 3 } & $10^{2} \mathrm{cfu} / \mathrm{ml}$ & $10^{7} \mathrm{cfu} / \mathrm{ml}$ \\
\hline 50 & $140 \mathrm{~min}$ & $160 \mathrm{~min}$ \\
55 & $90 \mathrm{~min}$ & $120 \mathrm{~min}$ \\
60 & $30 \mathrm{~min}$ & $40 \mathrm{~min}$ \\
65 & $15 \mathrm{~min}$ & $20 \mathrm{~min}$ \\
70 & $15 \mathrm{sec}$ & $25 \mathrm{sec}$ \\
75 & $10 \mathrm{sec}$ & $15 \mathrm{sec}$ \\
80 & $5 \mathrm{sec}$ & $10 \mathrm{sec}$ \\
\hline
\end{tabular}




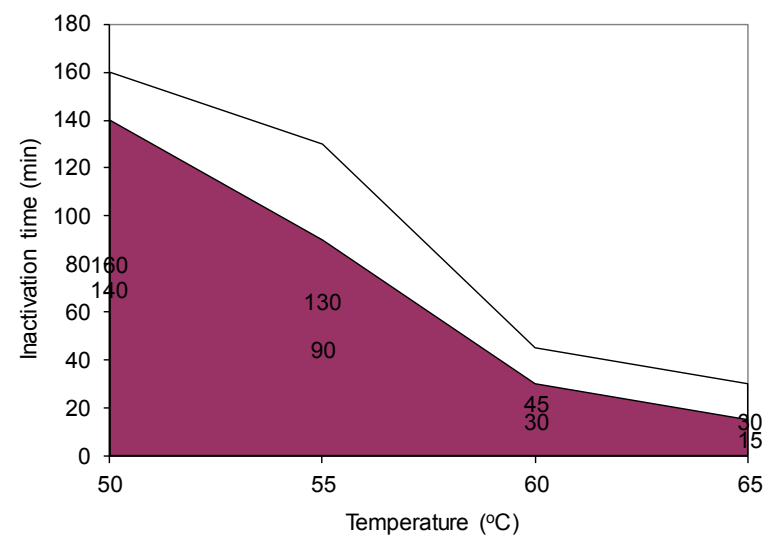

Figure 1a: Comparison of LTLT treatment and temperature-time combinations in eliminating $L$. monocytogenes FSTLC2 in milk at populations of $10^{2}$ and $10^{7} \mathrm{fu} / \mathrm{ml}$

findings remains controversial.

The temperature-time combinations required for inactivation of $L$. monocytogenes suspended in milk at population levels of $10^{2}$ and $10^{7} \mathrm{cfu} / \mathrm{ml}$ as observed in the model experiment (Table 1) are compared with LTLT and HTST pasteurization treatments (Figure 1a and 1b). The figures indicate that the risk area (representing temperature-time combinations of treatments) increases with the initial population of Listeria in milk. Thus, for a high Listeria population level of $10^{7} \mathrm{cfu} / \mathrm{ml}$, the LTLT and HTST pasteurization treatments fall inside the risk area.

It is safe to conclude that for a low Listeria population of less than $10^{2} \mathrm{cfu} / \mathrm{ml}$, LTLT and HTST treatments may always be inside the safe area. When the Listeria population increases, the chances of LTLT and HTST treatments falling in the boundary or risk area also increases, thus, making pasteurization ineffective. It is therefore evident that, if milk is contaminated with a heavy population of Listeria $\left(>10^{7} \mathrm{cfu} / \mathrm{ml}\right)$, neither LTLT nor HTST treatments could be considered as reliable heat processing techniques. It was observed in a comparable study that the complete inactivation of $L$. monocytogenes in milk with an initial population of $10^{6}-10^{9} \mathrm{Lis}$ teria $\mathrm{cfu} / \mathrm{ml}$ cannot be accomplished within $30 \mathrm{~min}$ at $62,72,82$, or even $92^{\circ} \mathrm{C}$ (Donnelly et al. 1986). The thermal inactivation of Listeria in milk is associated with the initial load of the organism, the fat content, heat adaptation of the organism, and state of the organism in milk (free suspension or internalized).

In Sri Lanka, milk products such as curd, yogurt, and cottage cheese are produced at home level and in micro-enterprises. The heat processing techniques they use in eliminating microorganisms may not always be carefully controlled standard methods. They boil milk without taking into consideration the time factor. Even though such a boiling is adequate to eliminate a low Listeria population of

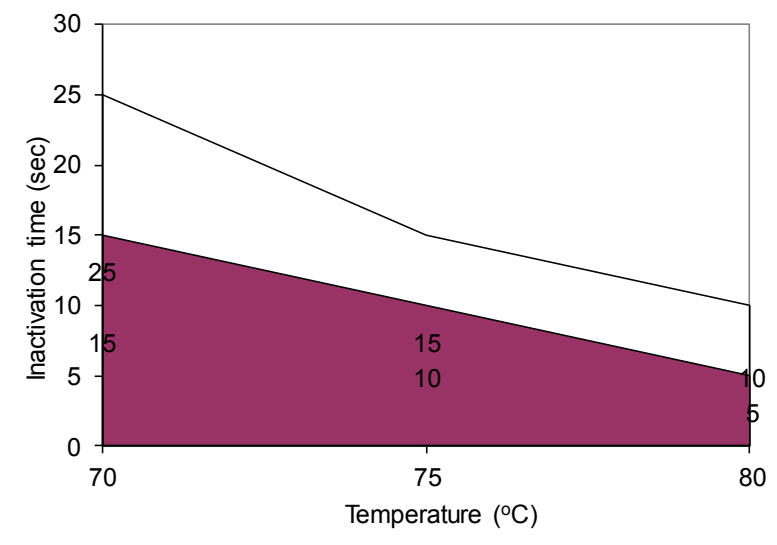

Fig. 1b: Comparison of HTST treatment and temperaturetime combinations in eliminating $L$. monocytogenes FSTLC2 in milk at populations of $10^{2}$ and $10^{7} \mathrm{cfu} /$ ml

less than $10^{2} \mathrm{cfu} / \mathrm{ml}$, it may not be adequate to eliminate a higher initial Listeria population of $10^{7} \mathrm{cfu} /$ $\mathrm{ml}$. Even though the possibility of the presence of a Listeria population of $10^{7} \mathrm{cfu} / \mathrm{ml}$ in raw milk was observed to be very low in this study, the observations cannot be extended to the variety of conditions operating during milking, collection, transport, storage and processing of milk leaving much room for rapid increase of Listeria populations to an infectious dose. The ubiquitous nature and the ability of L. monocytogenes to survive harsh environmental conditions also should not be ignored. The absence of proper chilling facilities, and long time-gap in between milking and processing add to the severity of the problem. With regard to pasteurized milk, there is always an associated risk, especially if proper thermal inactivation conditions are not practiced, because pasteurized milk is a ready-to-consume product, which would not be further processed.

\section{Thermal resistance of $L$. monocytogenes FSTLC55 isolated from pasteurized milk}

The present study showed that the thermal inactivation time for the L. monocytogenes FSTLC55, an isolate which had been obtained from a commercial brand of pasteurized milk in Sri Lanka, is higher than that for an isolate from raw cow milk (FSTLC2), at the same population of $10^{2} \mathrm{cfu} / \mathrm{ml}$ (Table 2).

The thermal inactivation times for L. monocytogenes isolate from raw cow milk (FSTLC2), introduced at different initial populations of $10^{2}$ and $10^{7}$ $\mathrm{cfu} / \mathrm{ml}$, and thermal inactivation times for the isolate from pasteurized milk (FSTLC55), at population of $10^{2} \mathrm{cfu} / \mathrm{ml}$, are illustrated in Figure 2. At the same population of $10^{2} \mathrm{cfu} / \mathrm{ml}$, L. monocytogenes isolate from pasteurized milk (FSTLC55) showed higher thermal resistance properties than 
Table 2: Comparison of thermal inactivation times for $\mathbf{L i s}-$ teria isolates from pasteurized milk (FSTLC55) and raw cow milk (FSTLC2) at population of $10^{2} \mathrm{cfu} / \mathrm{ml}$

\begin{tabular}{|c|c|c|}
\hline \multirow[t]{2}{*}{ Temperature $\left({ }^{\circ} \mathrm{C}\right)$} & \multicolumn{2}{|l|}{$\begin{array}{l}\text { Thermal inactiva- } \\
\text { tion time }\end{array}$} \\
\hline & $\begin{array}{l}\text { Isolate from raw } \\
\text { cow milk }\end{array}$ & $\begin{array}{l}\text { Isolate from } \\
\text { pasteurized milk }\end{array}$ \\
\hline 50 & 140mir & $160 \mathrm{~min}$ \\
\hline 55 & $90 \mathrm{mir}$ & $130 \mathrm{~min}$ \\
\hline 60 & 30mir & $45 \mathrm{~min}$ \\
\hline 65 & $15 \mathrm{mir}$ & $30 \mathrm{~min}$ \\
\hline 70 & $15 \mathrm{sec}$ & $50 \mathrm{sec}$ \\
\hline 75 & $10 \mathrm{sec}$ & $25 \mathrm{sec}$ \\
\hline 80 & $5 \mathrm{sec}$ & $15 \mathrm{sec}$ \\
\hline
\end{tabular}

the isolate from raw cow milk (FSTLC2) (Figure 2 ). It is also evident that the isolate from raw cow milk (FSTLC2), when suspended at $10^{7} \mathrm{cfu} / \mathrm{ml}$, showed higher thermal resistance than when suspended at populations $10^{2} \mathrm{cfu} / \mathrm{ml}$ (Figure 2). It is known that when the Listeria population increases in milk, the required thermal inactivation time also increases. The notable feature here is that the isolate from pasteurized milk needed higher heat treatment for inactivation than a population of $10^{7} \mathrm{cfu} /$ $\mathrm{ml}$ from raw milk. The elevated thermal resistance of $L$. monocytogenes isolates, observed especially in L. monocytogenes isolate from pasteurized milk, could be associated with following reasons:

It was reported that the fat in milk protects $L$. monocytogenes from heat. L. monocytogenes cells surrounded by milk fat are relatively much more heat stable (MacDonald and Sutherland 1993). The protective effect of milk fat is important during the maximum death region of the survival curve. Milk foods should not be processed at temperatures below $60^{\circ} \mathrm{C}$ because the shoulder regions become more pronounced and thermal processing may be under-estimated (Chhabra 1999). This is due to the buffering action and the poor thermal conductivity exerted by fat in milk.

In cases of naturally acquired listerial mastitis, the pathogen is normally not freely suspended in milk but rather exists as a facultative intracellular bacterium within phagocytic leukocytes (neutrophils and macrophages) present in milk (Tilney and Portnoy 1989). The partly intracellular nature of L. monocytogenes makes it possible that cells of the pathogen inside leukocytes could be partially protected from thermal inactivation and thus are more able to survive pasteurization than freely suspended cells of the bacterium in milk.

If L. monocytogenes is shed from infected cows, which have developed fever, the pathogen may have grown at elevated temperatures. It was reported that when Listeria was grown at $43^{\circ} \mathrm{C}$ before heating and recovered by anaerobic incubation after

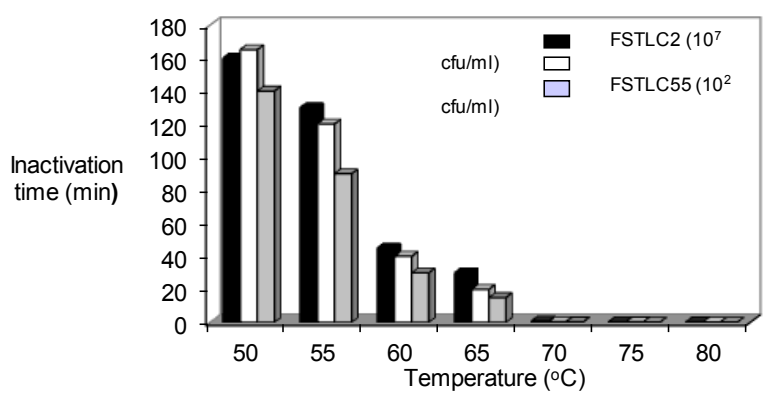

Figure 2: Comparison of thermal inactivation times for $L$. monocytogenes isolates from pasteurized milk (FSTLC55) and raw cow milk (FSTLC2)

the treatment, the $\mathrm{D}_{62.8} \mathrm{o}_{\mathrm{C}}$ value was $243 \mathrm{sec}$ as compared with $36 \mathrm{sec}$ when the pathogen was grown at $37^{\circ} \mathrm{C}$ and plated aerobically after the heat inactivation (Knabel et al., 1990) suggesting that cows who have developed fever may harbor organisms which are more heat resistant. It is also believed that Listeria cells inside macrophages are exposed to anaerobic conditions. It is possible that a few heat-injured cells remaining after the minimum HTST milk pasteurization may grow under anaerobic conditions that may exist in phagocytes. It is reported that adaptation to the environmental stresses such as high/low temperature, acidic and oxidative conditions, and starvation occurs in all bacteria, including L. monocytogenes (Mims 1987). An increasing number of parameters such as temperature, salt, $\mathrm{pH}$, heat shock, and oxidative stress, have been shown to affect virulence gene expression in L. monocytogenes (Brehm et al. 1996). Resistance of L. monocytogenes to heat or other lethal factors can be increased by heat shock or adaptation to other stresses. It was reported that bacteria respond to heat shock by synthesizing new proteins, termed heat-shocked proteins (HSPs), and these proteins usually increase the thermo-tolerance of microorganisms (Craig et al. 1993). Heat-shock and other environmental stresses are also reported to affect the virulence of L. monocytogenes. Environmental stresses are sensed by pathogens as sig-

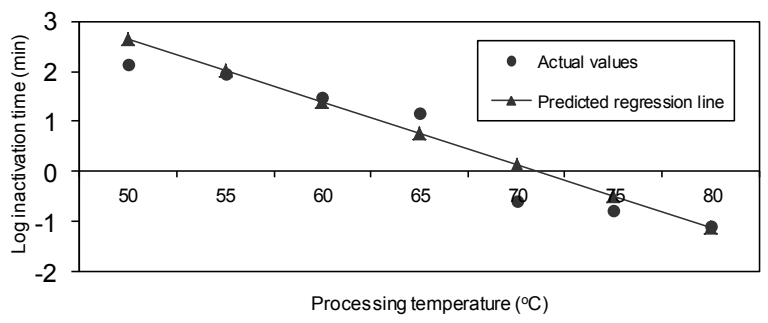

Figure 3: Regressed TDT curve for $L$. monocytogenes FSTLC2 suspended in bovine milk at populations $10^{5} \mathrm{cfu} / \mathrm{ml}$ 
nals for expression of virulence factors to enhance survival (Archer, 1996). Heat shock may also increase the virulence of $L$. monocytogenes enhancing more listeriolysin $\mathrm{O}$ production.

It is evident that L. monocytogenes, at times, shows unexpectedly higher thermal resistance to normal pasteurization protocols practiced in the dairy processing industry. Therefore, it is essential that the thermal processing techniques be reviewed at regular intervals in order to ensure the effectiveness of them.

\section{Determination of $\mathrm{z}$ value for $L$. monocytogenes using the Thermal Death Time (TDT) curve}

A z value of $7.6^{\circ} \mathrm{C}$ was observed for $L$. monocytogenes FSTLC2 isolated from raw cow milk. The $\mathrm{z}$ value is the temperature in centigrade required to make a tenfold change in the Thermal Death Time (TDT) curve. The regression line of the TDT curve for the L. monocytogenes FSTLC2 suspended in sterilized milk is illustrated in Figure 3. Thermal processing is the most widely used method to preserve food and to check harmful microorganisms to ensure safety for human consumption. TDT and TDR curves give general insight into the thermal inactivation of an organism during heat processing. The $\mathrm{z}$ values of 6.5 (Bradshaw et al. 1987), 7.3 (Bunning et al. 1986), 8.0 (Bunning et al. 1988), and 6.3 (Bradshaw et al. 1985) were reported for $L$. monocytogenes in milk. The apparent difference of the $\mathrm{z}$ value of the present study from other reported studies could be attributed to the food system used in the experiments. Some scientists used skim milk (Bradshaw et al. 1987), whereas other scientists used whole milk (Bunning et al. 1988). The fat content is higher in whole milk thus giving protective effects to L. monocytogenes against heat processing. This is partly due to the poor thermal conductivity in high fat milk foods. The higher the fat content in milk foods, the higher will be the $\mathrm{z}$ value. Food system used in the present study was sterilized whole milk. Therefore, it is possible that the relatively high $\mathrm{z}$ value $\left(7.6^{\circ} \mathrm{C}\right)$ observed is due to the buffering action of fat in milk. The $\mathrm{z}$ value observed in the present study is of the same order as reported $\mathrm{z}$ values, but high.

\section{Determination of the Decimal Reduction Time (D) for L. monocytogenes using the TDR curve}

A decimal reduction time $\left(\mathrm{D}_{71.7^{\circ}} \mathrm{C}\right)$ of $2.9 \mathrm{sec}$ was observed for L. monocytogenes FSTLC2- which had been isolated from raw cow milk- suspended in sterilized whole milk at populations $10^{5} \mathrm{cfu} / \mathrm{ml}$ (Fig. 4). Thermal Death Rate (TDR) curve was constructed using the survival number of $L$. monocytogenes isolate suspended in sterilized milk with processing time $(\mathrm{sec})$ at $71.7^{\circ} \mathrm{C}$. By definition, $\mathrm{D}$ value

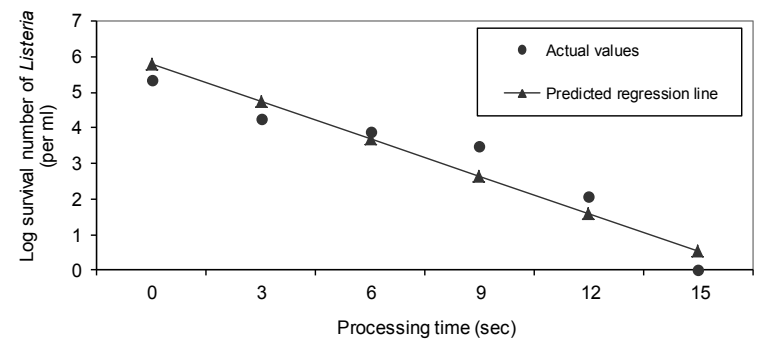

Figure 4: Regressed TDR curve for $L$. monocytogenes FSTLC2 suspended in bovine milk at populations $10^{5} \mathrm{cfu} / \mathrm{ml}$ at $71.7^{\circ} \mathrm{C}$

Predicted regression model: $\mathrm{X}=16.5-2.84 \mathrm{Y}$

$\mathrm{X}=$ Processing time $(\mathrm{sec}), \mathrm{Y}=\log$ survival number of Listeria, $\mathrm{r}^{2}=91.0, \mathrm{p}=0.003$

is the time required to eliminate $90 \%$ of the organism at a given temperature, which is $71.7^{\circ} \mathrm{C}$ in the present experiment.

Some of the reported $\mathrm{D}_{71.7}{ }^{\circ} \mathrm{C}$ values in milk for $L$. monocytogenes include 1.7 sec (Bradshaw et al. 1987), 3.1 and 5.0sec (Bunning et al. 1988), and 1.9 sec (Bunning et al. 1986). The differences, in the observed D value in the present study and reported $\mathrm{D}$ values, are once again due to the different milk food systems used in the respective experiments. Some scientists used skim milk (Bradshaw et al. 1987), whereas other scientists used whole milk (Bunning et al. 1988) in thermal resistance studies. Sterile whole milk was used in the present study as well. The fat content is higher in whole milk thus giving some protective effects to $L$. monocytogenes against heat processing.

The higher the $\mathrm{D}$ and $\mathrm{z}$ values, the longer it takes to eliminate L. monocytogenes from milk foods. It is apparent that it takes longer times to eliminate Listeria added to sterile whole milk where fat content is high. The observed $\mathrm{D}_{71.7}{ }^{\circ} \mathrm{C}$ value of the present study is comparable with those of other thermal resistance studies, and lies in between reported extreme $\mathrm{D}_{71.7}{ }^{\circ} \mathrm{C}$ values of $0.9 \mathrm{sec}$ (Bradshaw et al. 1985) and 5.0sec (Bunning at al. 1988). These observations suggest that $L$. monocytogenes isolates used in the present study show average thermal resistance properties.

The $\mathrm{z}$ and $\mathrm{D}$ values observed could be effective tools for food processing in Hazard Analysis and Critical Control Point (HACCP) plans, risk assessment models, and product development formulations in Sri Lankan perspective. Given the consequences of human listeriosis outbreaks, it may be necessary to encourage milk processing plants in general and milk pasteurizing plants in particular in Sri Lanka to review their thermal processing techniques to ascertain whether they are on par with the observed $\mathrm{z}$ and $\mathrm{D}$ values. 


\section{CONCLUSIONS}

Normal pasteurization techniques such as LTLT and HTST protocols can effectively eliminate a low population level $\left(10^{2} \mathrm{CFU} / \mathrm{ml}\right)$ of Listeria, but not a high population $\left(10^{7} \mathrm{CFU} / \mathrm{ml}\right)$ level in milk. Therefore, the current heat treatment techniques used in the dairy industry need to be reviewed and necessary modifications introduced in order to ensure a complete elimination of this pathogen in milk and milk products in Sri Lanka. Moreover, the $\mathrm{z}\left(7.6^{\circ} \mathrm{C}\right)$ and $\mathrm{D}_{71.7^{\circ}} \mathrm{C}(2.9 \mathrm{sec})$ values observed in the present study may be used in devising sound heat treatment techniques as well as suitable Hazard Analysis Critical Control Points (HACCP) systems in the dairy industry.

\section{Acknowledgements}

The authors gratefully acknowledge the assistance given by Mr PK Liyanage (Dept of Food Science \& Technology, University of Peradeniya) and Mrs S Abeysekare (Dept of Food Science \& Technology, University of Ruhuna) in preparing microbiological media and taking readings.

\section{REFERENCES}

Archer DL 1996 Preservation microbiology and safety: evidence that stress enhances virulence and triggers adaptive mutations. Trends Food Sci. Technol. 7: 91-95.

Bandaranayaka A and Nair VK 1962 Listeriosis in buffaloes. Cey. Vet. J. 10: 42-45.

Bandaranayaka A, and Fernando WWHS 1962 A note on the isolation of Listeria monocytogenes from the heart blood of a goat. Cey. Vet. J. 10: 46-47.

Bradshaw JG, Peeler JT, Corwin JJ, Hunt JM and Twedt RM 1987 Thermal resistance of Listeria monocytogenes in dairy products. J. Food Prot. 50: 543-544.

Bradshaw, J.G., Peeler, J.T., Corwin, J.J., Hunt, J.M., Tierney, J.T., Larkin, E.P., and Twedt, R.M. (1985). Thermal resistance of Listeria monocytogenes in milk. J. Food Protect. 48: 743 $-755$.

Brehm, K., Kreft, J., Ripio, M.T., and VazquezBoland, J.A. (1996). Regulation of virulence gene expression in pathogenic Listeria. Microbiol. Sem. 12: 219-236.

Bunning, V.K., Crawford, R.G., Bradshaw, J.G., Peeler, J.T., Tierney, J.T., and Twedt, R.M., (1986). Thermal resistance of intracellular Listeria monocytogenes cells suspended in raw bovine milk. Appl. Environ. Microbiol. 52: 13981402.

Bunning VK, Donnely CW, Peeler JT, Briggs EH, Brawshaw JG, Crawford RG, Beliveau CM and
Tierney JT 1988 Thermal inactivation of Listeria monocytogenes within bovine milk phagocytes. Appl. Environ. Microbiol. 54: 364-370.

Bunning VK, Crawford RG, Tierney JT and Peeler JT 1992 Thermotolerance of heat-shocked Listeria monocytogenes in milk exposed to hightemperature short-time pasteurization. Appl. Environ. Microbiol. 58(6): 2096-2098.

Chhabra AT, Carter WH, Linton RH and Cousin MA 1999 A predictive model to determine the effects of $\mathrm{pH}$, milkfat, and temperature on thermal inactivation of Listeria monocytogenes. $J$. Food Prot. 62(10): 1143-1149.

Dedie K and Schulze D 1957 Die Hitzeresistenz. von Listeria monocytogenes in Milch. Berl. Munchener tierarztl. Wochenscher. 70: 231-232.

Donnelly CW, Briggs EH and Baigent GJ 1986. Analysis of raw milk for the epidemic serotype of Listeria monocytogenes linked to an outbreak of listeriosis in California. J. Food Prot. 49: 846 -847 (Abstract).

Farber JM and Peterkin PI 1991 Listeria monocytogenes, a food-borne pathogen. Microbiol. Rev. 55: 476-511.

Fleming DW, Cochi SL, Macdonald KL, Brondum, J, Hayes PS, Plikaytis BD, Holmes MB, Audurier A, Broome CV and Reingold AL 1985 Pasteurized milk as a vehicle of infection in an outbreak of listeriosis. New Eng. J. Med. 312(7): 404-407.

Gunasena DK, Kodikara CP, Ganepola K, Widanapathirana S 1995 Occurrence of Listeria monocytogenes in food in Sri Lanka. J. Natn. Sci. Coun. Sri Lanka. 23(3): 107-114.

Jayamanne VS, and Samarajeewa U 2001 Incidence and detection of Listeria monocytogenes in milk and milk products of Sri Lanka. Trop. Agric. Res. 13: 42-50.

Jayasundera LBT, Goonathilleke PDP and Fernando NI 1962 A fatal case of meningitis due to Listeria (Erysipelothrix) monocytogenes. Cey. Med. J. 7: 221-225.

Knabel SJ, Walker HW, Hartman PA and Mendonca AF 1990 Effects of growth temperature and strictly anaerobic recovery on survival of Listeria monocytogenes during pasteurization. Appl. Environ. Microbiol. 56: 370-376.

Karakolev R 2009 Incidence of Listeria monocytogenes in beef, pork, raw-dried and raw-smoked sausages in Bulgaria. Food Control. 20(10): 953 $-955$.

Mackey BM and Bratchell N 1989 The heat resistance of Listeria monocytogenes. Let. Appl. Microbiol. 9: 89-94.

MacDonald F and Sutherland AD 1993 Effect of heat treatment on Listeria monocytogenes and Gram-negative bacteria in sheep, cow, and goat milks. J. Appl. Bacteriol.75(4): 336-343.

Maijala R, Lyytikainen O, Johansson T, Autio T, 
Aalto T, Haavisto L and Honkanen-Buzalski T

2001 Exposure of Listeria monocytogenes within an epidemic caused by butter in Finland. Int. J. Food Microbiol.70:97-109.

Mims CA 1987 The encounter of the microbe with the phagocytic cell. In: The Pathogenesis of Infectious Diseases. Orlando, FL: Academic Press. Pp. 63-91.

Ozgen H 1952 Zur Serologic der Listeria monocytogenes. Z. Tropenmed. 4: 40-45.

Rocourt J, Jacquet C and Reilly A 2000 Epidemeology of human listeriosis and seafoods. Int. J. Food Microbiol. 67:197-209.

Stenberg H and Hammainen T 1955 On determination in vitro of the resistance of Listeria monocytogenes to sodium chloride and heat on experimental monocytosis in albino mice. Nord. Vet. Med. 7: 853-868.
Tilney LG and Portnoy DA 1989 Actin filaments and the growth, movement, and spread of the intracellular bacterial parasite, Listeria monocytogenes. J. Cell Biol. 109: 1597-1608.

United States Department of Agriculture 1999 Consumer Information from USDA, Food Safety Education Office, Food Safety and inspection service, USDA, Washington D.C. 20250-3700, USA.

Wijesundera $\mathrm{C}$ de $\mathrm{S}$, Pinto MRM and Navaratnam C 1992 Two cases of listeriosis. Cey. Med. J. 37: 21-23.

Withana KA and Mirando EH 1967 Meningitis caused by Listeria monocytogenes. Cey. Med. J. 12: 37-39. 